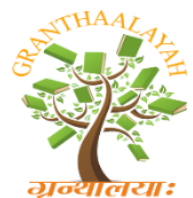
\author{
GRANTHAALAYAH \\ A knowledge Repository
}

INTERNATIONAL JOURNAL OF RESEARCH -

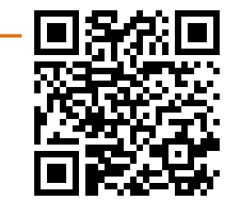

Management

\title{
RELATIONSHIP BETWEEN TALENT MANAGEMENT PRACTICES AND ORGANIZATIONAL PERFORMANCE IN ISLAMIC BANKS IN KENYA
}

\author{
Moza Abdallah Soud ${ }^{1}$, Ogolla, D. A. ${ }^{2}$, Mureithi S ${ }^{2}$ \\ ${ }^{1}$ School of Business and Economics, Kenya Methodist University, Kenya \\ ${ }^{2}$ Department of Business Administration
}

\begin{abstract}
Stringent business environment, shareholders' expectations on financial returns and the realization of companies' goals are some of the factors that have led to team leaders embracing talent management initiatives at various places of work. Innovation, demographic changes, competition and the advancement in technology have made leaders lose highly able and skilled staff to their rivals. To minimize losing competent staff, organizations must set aside sufficient resources and time to embed talent management initiatives across their firms. The purpose of this study was to examine the relationship between talent management practices and organizational performance in Islamic banks in Kenya. The researcher adopted the following factors: recruitment, selection, learning \& development and employee retention to examine their impact on organizational performance. The study targeted 100 respondents from the three Islamic banks in Kenya and used multivariate regression analysis to examine the relationships between the study variables. The researcher concludes that the three independent variables; recruitment, selection and learning \& development strongly impact organizational performance but not for employee retention which has no impact on organizational performance. Therefore, if these organizations are to achieve their desired objectives, they must adequately address the factors identified in this study.
\end{abstract}

Keywords: Talent Management; Islamic Banking; Performance; Kenya.

Cite This Article: Moza Abdallah Soud, Ogolla, D. A., and Mureithi S. (2020). "RELATIONSHIP BETWEEN TALENT MANAGEMENT PRACTICES AND ORGANIZATIONAL PERFORMANCE IN ISLAMIC BANKS IN KENYA." International Journal of Research - Granthaalayah, 8(3), 98-114. https://doi.org/10.29121/granthaalayah.v8.i3.2020.133.

\section{Introduction}

The creation of companies' competitive advantage can only be effective if leaders and business owners allocate a considerable amount of capital to foster employee's skills and competencies. Managers must ensure that they act on the potential of their employees by attracting the best by demonstrating that they can offer a clear and exciting career path. This, on the other hand, will be 
commensurate with organizations employing highly qualified and talented employees. For talent management to be effective, commitment and discipline must play a significant role throughout the organization. This will ensure that all staff members engage fully in the process through frequent discussions and action-plans aimed at enhancing employee career objectives. Skoludova and Brodsky (2015) established that for an organization to be successful, it must have the following; competent employees, an increase in revenue, quality of services offered and the increase in market shares which are the indicators of a successful company.

Thunnisen, Boselie and Fruytier (2013) found that identifying, selecting, developing and retaining the best employees in the organization who perform consistently must be given the opportunity for capacity building to ensure their future roles, which is a general concern of talent management. Effective talent management requires the link between organizations' strategy and talent management policy. This will enable stakeholders to have a clear understanding of the organization's position in the market environment. Ideally, the business strategy must emphasize more on the product's overall goal and the firm's competitive advantage such that talent management traces the strategy through attracting, selecting and engaging qualified personnel for the identified gaps (Cameron \& Pierce, 1996).

The lack of a highly talented and skilled workforce and competition makes the process of attracting and retaining talents one of the biggest concerns managers have globally (Bateman \& Snell, 2011). Human capital, on the other hand, is made up of acquired skills and knowledge solely expressed through talents and aptitudes which must be utilized fully to achieve both the individual and organizational needs. The implication of this is that organizational productivity is generally dependent on the quality and quantity of its workforce (Bateman \& Snell, 2011).

Companies that strive for competitive advantage should prioritize talent management initiatives as these drive organizational growth (Bateman, \& Snell, 2011). Moreover, talented employees who make positive impacts on the overall organizational performance through their contribution must be rewarded and retained (CIPD, 2007). In other words, Organizations desiring competitive advantage over their rivals must have talent management initiatives that would drive organizational growth. Thus, HR leaders must align their talent management initiatives with overall business goals (Bateman \& Snell, 2011). Sareen and Mishra (2016) argued that Organizational performance depends on how well companies manage and retain human resources. Ashton and Morton (2005) revealed that good talent management practices play an important role, especially when used to differentiate an organization's core competence and when its talent improves its strategy execution and operational excellence. Talent issues have undoubtedly been the most discussed agenda in meetings with organizations spending millions on the implementation of human resource information systems by revamping their HR processes. Talent management leaders still view talent management as a tactical problem instead of an integral part that requires top management support. Clark (2009) showed that in the next decade, there would be at most half a billion people working outside of their countries due to better remuneration packages. Furthermore the talent wars that emanated from the scarcity of competent staff have put retention strategies paramount to spearhead issues faced by organizations globally.

Despite this, most firms are yet to learn how to differentiate the approaches of talent management and the general HR programs with a great percentage of both local and multinational firms unable 
to come up with basic talent management strategies, which lay more emphasis on enhancing skills and competencies required for current and future gaps. As talent becomes more complex in this day and age, the capacity of an organization's ability to attract, develop, motivate and retain talent is expected to be a strategic issue for the 21st century's knowledge economies. Moreover, global demographics and economic forces have increased the mobility of people across world. As a result, it has led to a much wider diversity of culture, gender, working generation and various modes of employment like the introduction of flexible working hours, which was not practiced before (Casagrande, 2017).

A study conducted by the Malaysian World Islamic Finance Market place on Islamic finance talent development report in Africa (2016), established that staff who work in Islamic financial institutions must have a vast amount of expertise in the Islamic law (Shariah), finance and economic which will commensurate with the creation of employment and the overall enhancement of financial growth. Iqbal, Tahir, Aslam and Syed (2013) argued that it is hard to identify and breed staff with the right set of skills, attitudes and knowledge. Hence it is much easier to push staff to competition than to attract them, especially when looking for a unique set of skills.

In Canada, Hughes and Rog (2014) conducted a study on strategy for improving employee recruitment, retention and engagement within the hospitality industry. The proponents established whether recruitment, retention and employee commitment impact organizational goals. The study showed that top management buy-ins and their commitments are some of the strategies that help organizations control costs relating to searching for employees to fill vacant positions and engage staff considered competent. The study recommended that management should define talent management based on context. Top management supports and the linking of talent management initiatives are equally important.

Zakuan and Saian (2001) researched managerial selection practices in the Malaysian business environment using sample data from 62 small, medium and large business organizations. The researcher found that job application forms, individual's bio-data referrals and recommendations were some of the selection practices most companies used to identify the right candidates. The study further revealed that cultural dimensions had no impact on selection practices while assessment centers were greatly used across the Malaysian business environment.

In Nigeria, Ndibe (2017) examined the effect of staff learning and development focusing on Nigeria's top bottling companies. The study adopted a survey research design and used a questionnaire to collect data from 120 respondents. The information collected was analyzed and represented using tables. The results showed that employee training and development had a strong positive relationship with organizational goals achievement. The researcher concluded that the management team with the help of the human resources must adopt timely payments of salary as it will help focus more on deliverables than having to worry about unpaid bills.

On the subject of employee retention, Gicho (2015) researched the Eagle Africa Insurance Bookers in Kenya. The researcher adopted a descriptive research design with a sample consisting of 85 employees using questions derived from the objectives used in her study. Data were analyzed using descriptive and inferential statistics and presented using charts and bar graphs. The study concluded that the inability for management to pay sufficient bonuses, which matches the work 
done, and unrealistic work schedules are some of the reasons that make staff leave their places of work for better packages and flexible work environment.

Losing talented staff earmarked as high potential who are well conversant with Islamic law, finance, economics and who have been identified as successors to take up leadership roles when need arises to competition, has seen Islamic Banks in Kenya invest their capital by directing resources to persons identified as talent, only for them to leave to other organizations in search of fulfilling work opportunities, career progression and substantial pay. As a result, finding people who have the right competencies and capabilities to fill the gap has proven to be more costly, especially on total time spent during the recruitment process and for the new staff to blend into the new culture and work environment and be trained because Islamic Banking model requires employees to have specialized skills on Islamic law, finance and economics.

This study therefore sought to examine the relationship between talent management practices and organizational performance in Islamic Banks in Kenya. The following specific objectives were established.

- To assess the effects of recruitment on organizational performance in Islamic banks in Kenya.

- To examine the influence of selection on organizational performance in Islamic banks in Kenya.

- To investigate the influence of learning and development on organizational performance in Islamic banks in Kenya.

- To determine the effect of employee retention on organizational performance in Islamic banks in Kenya.

\section{Theory and Hypothesis}

This study adopted the following theories: the Herzberg two factor theory of motivation, the resource based view theory and the super's theory of individual's learning and development as described below.

\section{Herzberg Two Factor Theory of Motivation}

This theory was developed by Herzberg in (1959). Herzberg argued that for organizations to achieve employees' well-being as far as the role being carried out is concerned, job satisfaction is intrinsic and can be only be obtained from an individual assigned role or task. This is because the inability of a firm to provide individuals with an enabling work environment may be a result of unfulfilled job desires (Sharpe, Martin \& Roth, 2011).

Wall, Wood and Leach (2004) revealed that job enrichment enables individual's play their strengths in the assigned roles. The proponents assert that job satisfaction is central and could only be obtained from an individual's workload. Failure for organizations to provide a conducive work environment may ultimately be a cause for unfulfilled job desires. Thus, job enrichment aims to enhance an individual skill variety, responsibility span hence minimize dissatisfaction, work rigidity, tediousness which may be a result of doing repetitive work. Whereas empowerment allows staff to have a say or input on matters pertaining their day to day assignments. The reason 
behind all this is to allow staff especially those in junior positions air their views and grievances (Yohe \& Hatfield, 2003).

\section{Resource Based-View Theory}

The Resource-Based View was proposed by Barney (2003). He asserts that resources form an integral part of an organization, especially when business owners want to create a competitive advantage over their rivals. According to Helfat and Peteraf (2003), a resource refers to as an asset or input that assist in production, while a firm's capability refers to an organization's ability to carry out assigned roles and responsibilities - this could be the result of the utilization of the firms' resources aimed at achieving particular goals.

Rivard, Raymond and Verreault (1997) argued that any organization that waits to build or create an organization's competitive edge may do so by increasing its company's capacity to charge more for goods or services produced or offered to clients which in the long run will resonate to achieving the company's bottom line. The conceptual framework of the RBV helps establish important components of the theory that aid the understanding and application of the RBV. The foremost among the five components are the Resources. The resources here comprise assets, capabilities, organizational processes, available resources, communication and understanding of the organization's performance and commitment.

\section{Supers Theory on Individuals Learning and Development}

Super's theory on career development was promulgated in the 1950s. This theory does not only laid great emphasis on an individual's longevity to his choice on career and adaptations but also provides gradual transformation that the majority of individuals go through on various stages of their career lives (Super, 1969). The Supers' theory put forward some distinct phases of an individual's career lifecycle that are drawn from the exertion of sociologist and developmental psychologist who examined the various phases of a person's work and life respectively.

Osipow, Doty and Spokane (1985) argued that the Super theory pays little attention to social and economic factors which play an important role in an individuals' decision-making regarding life in general and career choices. Salomone (1996) on his review on supers' theory, showed that it is almost impossible to match Supers theory simply because of the continuous amendments Supers made over the years.

\section{Empirical Literature Review \\ Recruitment, Selection and Organizational Performance}

Ezeali and Esiagu (2010) defined recruitment as procedure organizations use to identify and employ competent staff to fill vacant positions aimed at driving the organization's strategic objective. Ekwoaba, Ikeije and Ufoma (2015), on recruitment and selection methods of companies performance in Nigeria, established that despite having a policy that governs and guides the recruitment processes, the researchers concluded that both recruitment \& selection criteria had a strong significant relationship on organizational performance.

According to Rynes and Barber (1990), showed that larger companies with large amounts of capital have an added advantage over their juniors (Smaller Organizations) when it comes to the implementation of highly complex yet effective recruitment processes. Smaller Organizations, on 
the other hand, focused more on cost-effective methods such as referrals and advertising through various means as their best alternative.

Rees and Smith (2017) revealed that seven in ten organizations focused their recruitment and talent management practices to find talents in niche areas. Moreover, 50 percent developed more talent in-house and used new modes of technology to recruit. The proponents further revealed that in 2017, most Organizations anticipated a greater focus on developing more talent in house and shifting the focus on retaining rather than recruiting talents and investing more time and effort in the quality of candidates.

\section{Learning and Development on Organizational Performance}

Training is the systematic process of altering the behaviors and attitudes of staff aimed at enhancing both individual and organizational performance. According to Fanibuyan (2001), it can also be an organized activity aimed at the importation of knowledge which will help individuals attain the required level of knowledge or skill (Dabale, Jagero, \& Nyauchi, 2014), whilst development involves preparing employees to cater for future roles (Obi-Anike, \& Ekwe, 2014). Hafeez and Akbar (2015) state that every single industry must deal with activities that successfully attain their standard. In the words of Antonacopoulou (2000), employee development must be recognized by the employees who want to learn or are willing to learn and must show interest to learn. Samwel (2018) on his study conducted in Tanzania (Shinyanga and Mara regions) on selected companies majoring in drilling in Geita on how training plays a major role in organizational performance. He later used 219 respondents hence used a simple random \& purposive sampling method. Again, questionnaires were used in the actual collection of data. Also, the results obtained were presented using tables. The researcher concluded that, for improved organizational performance, drilling companies must put in place a training and development policy and persons in charge of training should lay their great emphasis on management training. Kareem (2019) examined the impact of HRD on the effectiveness of organizations on governmentowned institutes of higher learning. The researcher used a survey to collect data and examined using CFA (Confirmatory factor analysis) and SEM (Structured equation modeling). The researcher concluded that all variables used strongly impacted organizational performance human resource development and organizational development of 342 staff. Sanyal and Hisam (2018) studied training and development and the impact it has on individual performance in selected banks in Sultanate, Oman. They established that the variables used had a strong positive relationship on employee performance. This was done by gathering data on 300 employees and used regression analysis and ANOVA for analysis.

\section{Employee Retention Strategies on Organizational Performance}

Sandhya and Kumar (2011) viewed employee retention as a process of engaging staff to stay committed to an organization for his/her work life period. Peoples' issues have been assumed to be more important than they were years ago. Consequently, 68 percent of the leaders prefer the idea of breeding staff internally because it is cheaper and saves time when compared to hiring externally (Falola, Oludayo, Ignoba, Salau and Borishade, 2018).

A statistical report on talent retention in 2008, established that Employee turnover was arguably costly to an Organization with direct replacements costs ranging from 50 percent to 60 percent of an average employee annual salary. In addition, total costs associated with turnover ranged from 
90 percent to 200 percent annual salary. Needless to say, it is estimated that turnover related costs represents more than 12 percent pretax income for the average company and nearly 40 percent for Company's at the 75th percentile for turnover rate (Allen, 2008).

Employee recognition report was done by Sourchi and Liao (2015) on HR practitioners deduced that $40 \%$ of HR practitioners believed that cited staff turnover was their highest structural challenge tailed, which was closely followed by staff engagement at 39 percent, while 29 percent said they were most worried about finding replacement talent. Lastly, the findings on managing culture were at 24 percent respectively. Acquiring and retaining staff who poses the right competencies are some of the factors that give birth to talent scarcity. Labor shortage which is the result of insufficient learning programs, demographic shifts are what manpower equate it to lack of sufficient talent to cater to the growing needs of business worldwide.

\section{Methodology}

\section{Research Design}

This study used the descriptive research design to gather the research data simply because it is convenient and cost effective compared to other designs and can also convert qualitative data into qualitative data which is suitable for statistical analysis and presentation (Mugenda, 1999).

\section{Study Population}

The targeted population was made up of 100 employees obtained from the three Islamic Banks in Kenya, who work at the various departments such as; product development and Shariah Compliance (PDSC), retail banking, small \& medium-size enterprises (SME's), corporate banking, credit (which constitute, risk, administration, and recoveries), treasury, human resources, and operations. Again, the researcher targeted various categories of staff in the three levels management positions which include; heads of departments, line managers, and junior staff respectively.

\section{Data Collection Procedure}

Before collecting research data, a recommendation letter was obtained from the school and research license was also attained from the national research authority NASCOSTI and attached to the questionnaires which were submitted to the respondents' offices and collected after some time. Confidentiality and the rights of withdrawal were observed.

\section{Reliability and Reliability}

To establish the validity of this study, questionnaires were designed in ways that questions asked agreed with the conceptual framework. The researcher first administered pilot testing to establish the reliability of the study. A summary of the results showing as per the Cronbach's alpha of the items tested are shown in Table 1 below.

Table 1: showing Reliability Analysis

\begin{tabular}{|l|c|c|l|}
\hline Variable & Cronbach's alpha & No of items & Verdict \\
\hline Recruitment & 0.821 & 6 & Reliable \\
\hline Selection & 0.712 & 6 & Reliable \\
\hline Learning and development & 0.782 & 7 & Reliable \\
\hline
\end{tabular}




\section{Source: Research data (2019)}

\begin{tabular}{|l|l|l|l|}
\hline Employee Retention & 0.701 & 6 & Reliable \\
\hline Organization performance & 0.832 & 5 & Reliable \\
\hline
\end{tabular}

The analysis in table 1 suggests that the Cronbach's alpha values for all the study variables (dependent and independent) exceeded 0.7 thresholds. This indicates that the instruments employed were reliable enough to conduct the study and to make a conclusion.

\section{Data Analysis Methods}

The researcher used both inferential and descriptive statistics to analyze data obtained. For the quantitative presentation of results, SPSS version 22 was used to analyze the responses gathered from the questionnaires. For accuracy, consistency, and completeness of the data, questionnaires were re-examined to ensure it conforms to the study objective. Data collected was first classified, coded and then analyzed and presented using tables.

\section{Results and Discussion}

The study used mean and standard deviation to summarize data collected from the secondary records. ANOVA, regression analysis, and correlation statistics were also adopted to assess the relationship between the dependent and the independent variables.

\section{Response Rate}

This study targeted all staff who work in various departments and occupy the three management positions across the three Islamic Banks in Kenya. Emphasis was put on the heads of departments, line managers and junior staff who work in the Product Development and Shariah Compliance (PDSC), Retail Banking, Small \& Medium Size enterprises (SME's), Corporate Banking, Credit (which constitute, Risk, Administration, and Recoveries), Treasury, Human Resources and Operations. A total of 80 questionnaires were administered to the mentioned staff who work in the three Islamic Banks in Kenya. The response rate was 56 out of 80 questionnaires administered, which was sufficient for analysis and to make a conclusion.

Distribution of respondents according to gender: the study established the gender distribution of the respondents. The results were summarized in table 2 below.

Table 1: Gender of the Respondents

\begin{tabular}{|l|c|c|}
\hline Gender & Frequency & Percentage \\
\hline Male & 37 & 66 \\
\hline Female & 19 & 34 \\
\hline Total & $\mathbf{5 6}$ & $\mathbf{1 0 0}$ \\
\hline
\end{tabular}

Source: Research Data (2019)

The breakdown in Table 2 implies that the three Islamic banks in Kenya had gender disparity with a ratio of 2:1 which suggests that $66 \%$ of the total population were men whilst females were at $34 \%$ respectively. 
Distribution by age brackets of respondents. The participants were asked to indicate their highest level of education. The results were summarized and presented in Table 3 below.

Table 2: Age brackets of the Respondents

\section{Source: Research Data (2019)}

\begin{tabular}{|l|c|c|}
\hline Age brackets & Frequency & Percentage \\
\hline 21-25 years & 1 & 1.78 \\
\hline 26-30 years & 10 & 17.88 \\
\hline 31- 36 years & 24 & 42.85 \\
\hline 37-42 years & 16 & 28.57 \\
\hline Above 42 years & 5 & 8.92 \\
\hline Total & $\mathbf{5 6}$ & $\mathbf{1 0 0}$ \\
\hline
\end{tabular}

From the analysis in the above table 3 deduces that the majority of the respondents were in the age bracket of between 31-36 years, which amounted to $42.85 \%$. Those in the age bracket of 37 and 42 years were $28.57 \%$, while 42 above years was $8.92 \%$. Age brackets between 26 and 30 years were $17.88 \%$, while $21-25$ years was $1.78 \%$. The implication is that those in the Islamic Banks in Kenya were aged above twenty-five years.

Educational level: the respondents were requested to indicate their level of education. The results obtained were analyzed and presented in table 4 below.

Table 4: Educational level of participants

\begin{tabular}{|l|c|c|}
\hline Education level & Frequency & Percentage \\
\hline Diploma & 14 & 24.98 \\
\hline Bachelors & 30 & 53.57 \\
\hline Masters & 10 & 17.88 \\
\hline PhD & 2 & 3.57 \\
\hline Total & $\mathbf{5 6}$ & $\mathbf{1 0 0}$ \\
\hline
\end{tabular}

\section{Source: Research Data (2019)}

Findings in Table 4 indicate that $53.57 \%$ of the respondents had bachelor's degrees, $24.98 \%$ had a diploma, and $17.88 \%$ had a master's degree while $3.57 \%$ of the respondents had a doctorate. This shows that all participants who took active roles were well conversant with the jargon used hence were able to give reliable information that supports the objective of this study.

Distribution by working experience in the organization for the participants: Participants were asked to indicate the total number of years each one of them served while working for their employers. Results are summarized in table 5.

Table 5: Work experience in the organization

\begin{tabular}{|l|c|c|}
\hline Duration & Frequency & Percentage \\
\hline Below 2 years & 4 & 7.14 \\
\hline 2-6 years & 30 & 53.58 \\
\hline
\end{tabular}




\begin{tabular}{|l|c|c|}
$7-10$ years & 18 & 32.14. \\
\hline Above 10 years & 4 & 7.14 \\
\hline Total & $\mathbf{5 6}$ & $\mathbf{1 0 0}$ \\
\hline
\end{tabular}

\section{Source: Research Data (2019)}

The results shown above indicate that at most $53.58 \%$ of the respondents have worked in their respective companies between 2 and 6 years, 32.14\% have worked for their respective companies between $7-10$ years while $7.14 \%$ have worked for their respective companies below 2 years as well as those who have worked for their respective companies above 10 years. These findings are in agreement with the notion that gives a clear dispensation that all participants have a vast amount of experience and exposure enough and were conversant with the relationship between talent management practices and organizational performance in Islamic Banks in Kenya: therefore, they gave invaluable information for the study.

Management Level: the researcher asked the participating individuals to specify their levels of management positions. The results were analyzed and summarized in table 6 below.

Table 6: Level of Management

\begin{tabular}{|l|c|c|}
\hline Management Level & Frequency & Percentage \\
\hline Lower & 27 & 43 \\
\hline Middle & 13 & 27 \\
\hline Senior & 16 & 30 \\
\hline Total & $\mathbf{5 6}$ & $\mathbf{1 0 0}$ \\
\hline
\end{tabular}

Source: Research Data (2019)

The results in Table 6 above imply that the lower-level management was at $43 \%$, middle at $27 \%$, and senior roles at $30 \%$. This shows that the lower level management was in the majority, followed by senior-level management.

Working Experience in the Current Position: The participants were asked to indicate their work experience in their current positions regarding years spent in their current roles. The results were summarized and presented in table 7 below.

Table 7: Work Experience in Current Position

\section{Source: Research Data (2019)}

\begin{tabular}{|l|c|c|}
\hline Age brackets & Frequency & Percentage \\
\hline Below 5 years & 13 & 23 \\
\hline 5-10 years & 27 & 49 \\
\hline 11-15 years & 11 & 20 \\
\hline Over 15 years & 5 & 8 \\
\hline Total & $\mathbf{5 6}$ & $\mathbf{1 0 0}$ \\
\hline
\end{tabular}

The table above clearly shows that at most $49 \%$ of the participating individuals have been in their current roles between 5 and 10 years, $23 \%$ have operated in their current positions below 5 years, $20 \%$ have worked for their respective positions between 11-15years, while $8 \%$ have worked for 
their relevant companies between over 15 years. The implications of these findings show that the respondents have worked for a long time enough in their respective positions and were up-to-date with the relationship between talent management practices and organizational performance in Islamic Banks in Kenya; therefore, they gave invaluable information that supports the conclusion of the study.

Descriptive Statistics for Organization Performance: Participants selected for this research were asked to give their views and sentiments relating to organizational performance. The outcomes based on their responses are summarized below.

The results indicate that at a mean of 4.62, the majority of the respondents were in agreement that their organizations have put in place well-defined career plans which are congruent to both individual and organizational goals. This was closely followed by participants who agreed that they too have a well-defined articulated reward system aimed at awarding the best performers with an average score of 4.51. Those who sentiment about their organizations setting aside budget to automate most of their processes while ensuring continuous employee productivity had a mean of 4.29.

Descriptive Statistics for Recruitment: Individuals taking part in this research were asked to give comments on statements relating to employee recruitment. Their responses were analyzed below.

The results infer that most respondents agreed that their organizations have a robust graduate or management trainee programs that form part of their talent pool having a mean of 4.68, and a standard deviation of 0.543. This was followed closely by those who agreed that their organizations have set aside a substantial budget to cater for all the costs relating to external recruitments that include agencies with an average of 4.45. Redeployment scored the mean of 4.39, while promotion had the mean at 4.3 respectively.

Descriptive Statistics for Selection: The target respondents were asked to give their views and opinions on matters relating to employee selection. Their responses were analyzed and summarized below.

The majority of participants agreed that their organizations use knowledge-based tests to examine an individual understanding about the various aspects of a particular job with an average score of 4.68 , followed by personality test which had the mean of 4.45 and preliminary screening before selecting appropriate candidates at an average of 4.39 respectively.

Descriptive Statistics for Learning and Development: All the participating candidates were asked to give their comments and opinions on statements relating to individual learning and development as their responses are illustrated below.

As learning and developments forms an integral part as far as having competent staff is concerned. When asked, respondents were positive to note that having a competent Manager whose main focus is on Learning and Organizational development to solely dwell on plan, monitor and manage 
companies training budget and programs was key with an average mean of 4.04 followed by mentorship at an average of 4.02 and job rotation for junior staff which had an average of 3.95.

Descriptive Statistics for Employee Retention Strategies: Participants were asked to share their sentiments on statements relating to employee retention as illustrated below.

Leaders globally are of the notion that employee retention has been a major hurdle for most organizations worldwide. With some spending so much on staff, they consider talent. Therefore, this study wanted to find out how individuals participants were in agreement with the above statements. The majority were in agreement that their organizations have put in place avenues where all staff can air out their grievances with an average score of 4.11 , followed by 4.07 who agreed that their respective organizations have put in place mechanisms that promote work-life balance among employees having clear channels of communications, fairness, and equity with an average score of 3.66 and 3.57 respectively.

\section{Correlation Analysis}

The researcher used Pearson correlation analysis to show a linear association between the predicted and the result variables. The correlation analysis helped in establishing the strengths of the relationship in the model between the predictor variables and outcome variable as illustrated below.

Table 8: Relationship between Independent Variables

\begin{tabular}{|c|c|c|c|c|c|c|}
\hline & $\begin{array}{l}\text { Organization } \\
\text { performance }\end{array}$ & $\begin{array}{l}\text { Employee } \\
\text { Recruitment }\end{array}$ & \multicolumn{3}{|c|}{\begin{tabular}{|l|l|l} 
Learning and & Employee & Employee \\
development & Selection & Retention \\
\end{tabular}} \\
\hline \multirow[t]{3}{*}{$\begin{array}{l}\text { Organization } \\
\text { performance }\end{array}$} & \begin{tabular}{|l|} 
Pearson \\
Correlation
\end{tabular} & & & & & \\
\hline & $\begin{array}{l}\text { Sig. } \\
\text { tailed) }\end{array}$ & & & & & \\
\hline & $\mathrm{N}$ & & & & & \\
\hline \multirow{4}{*}{$\begin{array}{l}\text { Employee } \\
\text { Recruitment }\end{array}$} & Pearson & $812^{* *}$ & & & & \\
\hline & Correlation & & & & & \\
\hline & $\begin{array}{l}\text { Sig. } \\
\text { tailed })\end{array}$ & .000 & & & & \\
\hline & $\mathrm{N}$ & 56 & 56 & & & \\
\hline \multirow[t]{3}{*}{$\begin{array}{l}\text { Learning and } \\
\text { development }\end{array}$} & $\begin{array}{l}\text { Pearson } \\
\text { Correlation }\end{array}$ & $.771^{\text {** }}$ & $106^{* *}$ & & & \\
\hline & $\begin{array}{l}\text { Sig. } \\
\text { tailed })\end{array}$ & -.000 & .000 & & & \\
\hline & $\mathrm{N}$ & 56 & 56 & 56 & & \\
\hline \multirow[t]{3}{*}{$\begin{array}{l}\text { Employee } \\
\text { Selection }\end{array}$} & $\begin{array}{l}\text { Pearson } \\
\text { Correlation }\end{array}$ & $.649^{* *}$ & $104^{* *}$ & $.127^{* *}$ & & \\
\hline & $\begin{array}{l}\text { Sig. } \\
\text { tailed) }\end{array}$ & -.000 & .000 & .000 & & \\
\hline & $\mathrm{N}$ & 56 & 56 & 56 & 56 & \\
\hline $\begin{array}{l}\text { Employee } \\
\text { Retention }\end{array}$ & $\begin{array}{l}\text { Pearson } \\
\text { Correlation }\end{array}$ & $.681^{* *}$ & $.112^{* *}$ & $.131^{* *}$ & $.112^{* * *}$ & \\
\hline
\end{tabular}




\begin{tabular}{|l|l|l|l|l|l|l||}
\hline & $\begin{array}{l}\text { Sig. } \\
\text { tailed) }\end{array}$ & $(2-.000$ & .000 & .000 & .000 & \\
\hline $\mathrm{N}$ & 56 & 56 & 56 & 56 & 56 \\
\hline
\end{tabular}

The results in table 8 indicate that there is a positive correlation between recruitment and organization performance in Islamic Banks in Kenya at a significance level of 0.05 and the strength is significant at $81.2 \%$. The same findings showed a positive relationship between learning \& development to organization performance at a significance of 0.05 and the strength is strong at $77.1 \%$. The results further revealed that there is a positive correlation between employee retention and organization performance at a significance of 0.05 and the strength is at $68.1 \%$. Employee selection was found to have a negative relationship with an organizational performance at a significant level of 0.05 and the strength at $64.9 \%$.

\section{Relationship between Dependent and Independent Variables}

Table 9: Model Summary

\begin{tabular}{|c|c|c|c|c|}
\hline \multicolumn{5}{|c|}{ Model Summary $^{\mathbf{b}}$} \\
\hline Model & $\mathbf{R}$ & R Square & Adjusted R Square & Std. Error of the Estimate \\
\hline 1 & $.887^{\mathrm{a}}$ & .787 & .766 & .230 \\
\hline
\end{tabular}

\section{Source: Research Data (2019)}

As shown in table 9,78.8\% of the variation in organizational performance can be explained by changes in Recruitment, Selection, Learning and development, and Employee Retention, leaving only $21.3 \%$ unexplained (error term).

Table 10: Relationship between Independent Variables

\begin{tabular}{|l|c|c|c|c|c|}
\hline \multicolumn{7}{|c|}{ ANOVA $^{\mathbf{a}}$} \\
\hline Model & Sum of Squares & Df & Mean Square & F & Sig. \\
\hline 1 Regression & 9.845 & 4 & 2.461 & 46.433 & $.000^{\mathbf{b}}$ \\
\hline Residual & 2.655 & 50 & .053 & & \\
\hline Total & 12.500 & 55 & & & \\
\hline
\end{tabular}

a. Dependent Variable: Organization performance

b. Predictors: (Constant), Recruitment, Selection, Learning and development, Employee Retention Source: Research Data (2019).

The probability value of $p<0.00$ reveals that the model was completely significant. Specifically, Recruitment, Selection, Learning and development, and Employee Retention combined significantly influence organization performance in the Islamic banks in Kenya. 
The F calculated at 5\% level of significance was 46.433 since F calculated value is greater than the F critical value, this shows that the overall model was significant.

Table 11: Relationship between dependent and independent variables

\begin{tabular}{|c|c|c|c|c|c|c|}
\hline \multicolumn{7}{|c|}{ Coefficients $^{\mathbf{a}}$} \\
\hline \multirow{2}{*}{\multicolumn{2}{|c|}{ Model }} & \multicolumn{2}{|c|}{$\begin{array}{l}\text { Unstandardized } \\
\text { Coefficients }\end{array}$} & \multirow{2}{*}{$\begin{array}{c}\begin{array}{c}\text { Standardized } \\
\text { Coefficients }\end{array} \\
\text { Beta } \\
\end{array}$} & \multirow[t]{2}{*}{$\mathbf{t}$} & \multirow[t]{2}{*}{ Sig. } \\
\hline & & B & Std. Error & & & \\
\hline \multirow[t]{5}{*}{1} & (Constant) & 2.728 & 1.188 & & .176 & .176 \\
\hline & Recruitment & .302 & .095 & .176 & .065 & .005 \\
\hline & Selection & .131 & .074 & .065 & .276 & .021 \\
\hline & $\begin{array}{l}\text { Learning and } \\
\text { development }\end{array}$ & .274 & .101 & .276 & .095 & .000 \\
\hline & Employee Retention & .159 & .255 & .095 & .176 & .106 \\
\hline
\end{tabular}

\section{Dependent variable: Organization performance}

Source: Researcher Data (2019)

Using the beta coefficient, the established regression model was as follows:

$\mathrm{Y}=\mathbf{2 . 7 2 8}+\mathbf{0 . 3 0 2} \mathrm{X}_{1}+0.131 \mathrm{X}_{2}+0.274 \mathrm{X}_{3}+0.159 \mathrm{X}_{4}$

The coefficients in table 11 showed that for every one unit rise in Recruitment, organization performance increases by 0.302 units other factors held constant; every one unit increase in selection, organization performance increases by 0.131 units other factors held constant; every one unit increase in Learning and development, organization performance increases by 0.274 units other factors held constant; every one unit increase in Employee Retention organization performance increases by 0.159 units other factors held constant.

The results of the regression analysis showed that recruitment had the maximum positive influence on organization performance, second was learning and development, employee Retention, and Selection. The distinct sign of the predictor variables was verified using a t-test. The finding revealed that recruitment, selection, learning, and development, were statistically and significantly related to organization performance at a $\mathrm{p}$-value $<0.05$. While employee retention was not statistically and significantly related to the performance of Islamic banks in Kenya with p-value $.106>0.05$.

\section{Conclusion and Recommendation}

The purpose of this study was to examine the relationship between talent management practices and organizational performance in Islamic banks in Kenya. Specific objectives were to assess the effects of recruitment on organizational performance in Islamic banks in Kenya; to examine the influence of selection on organizational performance in Islamic banks in Kenya; to investigate the influence of learning and development on organizational performance in Islamic banks in Kenya and to determine the effect of employee retention on organizational performance in Islamic banks in Kenya. The regression results found a significant relationship between recruitment, selection, and learning \& development. Regarding retention, it was observed statistically insignificant to the organizational performance. This conclusion is in line with previous studies which suggest that 
recruitment strongly influences organizational performance together with selection and learning $\&$ development. The study, therefore, concluded that for Islamic banks in Kenya to produce the desired results and combat competitors' influence in the banking industry, they must put in place structures that would address the issue of recruitment in its full effect. Similarly, if these banks are to perform to expectations, they must institute measures that would properly address various methods used in selecting future employees. The same approaches must also be used for learning $\&$ development and employee retention. These results are achievable if the managers of the Islamic banks in Kenya are committed to addressing these factors identified in this study.

This study recommends that for organizations to adequately control the recruitment shortages, companies must strive to put in place policies and procedures that touch on multi-skilling, or preparing staff to tackle senior roles when the need arises by giving them acting appointments or through job shadowing. In addition, HR practitioners must work together with line managers to ensure that each staff has a well-defined career plan aimed at providing the right competencies for each individual's current or future roles. Job rotations, coaching and mentoring are some of the avenues line managers may use to prepare staff for bigger roles when the need arises. Managers must put in place practical succession plans for roles considered critical, especially when dealing with an aging workforce scheduled for retirement in the next four or five years' time. Finally, HR must set aside sufficient budget to cater for costs relating to external recruitment and graduate or management trainee programs which ideally will form part of an organization's talent pool.

\section{References}

[1] Allen, D. G. (2008). Retaining talent: A guide to analyzing and managing employee turnover. SHRM Foundations.

[2] Antonacopoulou, E. P. (2000). Employee development through self-development in three retail banks. Personnel Review, 29(4), 491-508.

[3] Barney, J. (1991). Special theory forum the resource-based model of the firm: origins, implications, and prospects. Journal of management, 17(1), 97-98.

[4] Bateman, T. S., \& Snell, S. (2011). Management: Leading \& collaborating in a competitive world.

[5] Bland, J. M., \& Altman, D. G. (1997). Statistics notes: Cronbach's alpha. Bmj, 314(7080), 572.

[6] Cameron, J., \& Pierce, W. D. (1996). The debate about rewards and intrinsic motivation: Protests and accusations do not alter the results. Review of Educational Research, 66(1), 39-51.

[7] Casagrande, M. (2017). Graduate programs in a talent management perspective, a comparative analysis of scope and structure.

[8] Clark, D. B. (2009). Talent Management Strategies for Public Procurement Professionals in Global Organisations.

[9] Dabale, W. P., Jagero, N., \& Nyauchi, M. (2014). The relationship between training and employee performance: the case of Mutare City council, Zimbabwe. International Journal of Human Resource Studies, 4(4), 61.

[10] Dahshan, M., Keshk, L., \& Dorgham, L. S. (2018). Talent Management and Its Effect on Organization Performance among Nurses at Shebin El-Kom Hospitals. International Journal of Nursing, 5(2), 108-123.

[11] Ekwoaba, J. O., Ikeije, U. U., \& Ufoma, N. (2015). The Impact of Recruitment and Selection Criteria on Organizational Performance.

[12] Ezeali, B. O., \& Esiagu, L. N. (2010). Public Personnel Management: Human Capital Management Strategy in the 12th century. Onitisha: Book point Limited. 
[13] Falola, H. O., Oludayo, O. O., Igbinoba, E. E., Salau, O. P., \& Borishade, T. T. (2018). Measuring work engagement strategies and employees' behavioural outcomes in Nigerian Universities. Journal of Business and Retail Management Research, 13(2), 98-106.

[14] Fanibuyan, A. (2001). Contemporary issues in human resources management and organizational behaviour.

[15] Gicho, M. M. (2015). The effect of employee retention strategies on employee performance: The case of Eagle Africa Insurance Brokers Limited (Doctoral dissertation, United States International University-Africa).

[16] Hafeez, U., \& Akbar, W. (2015). Impact of training on employees performance (Evidence from pharmaceutical companies in Karachi, Pakistan). Business Management and Strategy, 6(1), 49-64.

[17] Helfat, C. E., \& Peteraf, M. A. (2003). The dynamic resource-based view: Capability lifecycles. Strategic management journal, 24(10), 997-1010.

[18] Hughes, J. C., \& Rog, E. (2008). Talent management: A strategy for improving employee recruitment, retention and engagement within hospitality organizations. International Journal of Contemporary Hospitality Management, 20(7), 743-757.

[19] Kareem, M. A. (2019). The Impact of Human Resource Development on Organizational Effectiveness: An Empirical Study. Management Dynamics in the Knowledge Economy, 7(1), 2950.

[20] Kothari, C. R. (2004). Research methodology: Methods and techniques. New Age International.

[21] Mugenda, O. M. (1999). Research methods: Quantitative and qualitative approaches. African Centre for Technology Studies.

[22] Mugenda, O. M., \& Mugenda, A. G.(2003). Research methods.

[23] Ndibe, B. C., \& Campus, E. (2014). Effect of Employees Training on Organizational Performance in Soft Drinks Bottling Companies in Enugu State, Nigeria. Faculty of Business Administration, University of Nigeria Enugu Campus.

[24] Obi-Anike, H. O., \& Ekwe, M. C. (2014). Impact of training and development on organizational effectiveness: Evidence from selected public sector organizations in Nigeria. European Journal of Business and Management, 6(29), 66-75.

[25] Ong'anya, G. V., \& Ododa, H. O. (2009). Questionnaire as a Data Collection Instrument. Political Science. http://onganya. blogspot. com/2010/03/questionnaire-as-data-collection. html.

[26] Pearson, K., \& Lee, A. (1908). On the generalised probable error in multiple normal correlation. Biometrika, 6(1), 59-68.

[27] Rees, G., \& Smith, P. (Eds.). (2017). Strategic human resource management: An international perspective. Sage.

[28] Rivard, S., Raymond, L., \& Verreault, D. (2006). Resource-based view and competitive strategy: An integrated model of the contribution of information technology to firm performance. The Journal of Strategic Information Systems, 15(1), 29-50.

[29] Rynes, S. L., \& Barber, A. E. (1990). Applicant attraction strategies: An organizational perspective. Academy of management review, 15(2), 286-310.

[30] Salomone, P. R. (1996). Tracing Super's theory of vocational development: A 40-year retrospective. Journal of career development, 22(3), 167-184.

[31] Samwel, J. O. (2018). Impact of employee training on organizational performance: Case study of drilling companies in Geita, Shinyanga \& Mara Regions of Tanzania. International Journal of Management Studies and Research, 6(1).

[32] Sandhya, K., \& Kumar, D. P. (2011). Employee retention by motivation. Indian Journal of science and technology, 4(12), 1778-1782.

[33] Sanyal, S., \& Hisam, M. W. (2018). Impact of training and development on the performance of employees-A comparative study on select banks in sultanate of Oman. International journal of scientific research and management, 6(03). 
[34] Sareen, P., \& Mishra, S. (2016). A study of talent management and its impact on performance of organizations. Journal of Business and Management, 18(12), 66-73.

[35] Sharpe, J. P., Martin, N. R., \& Roth, K. A. (2011). Optimism and the Big Five factors of personality: Beyond neuroticism and extraversion. Personality and Individual Differences, 51(8), 946-951.

[36] Skoludova, J., \& Brodsky, Z. (2015). Current Trends of Selected Aspects of Human Resource Management in the Czech Republic. Procedia economics and finance, 26, 603-608.

[37] Sourchi, S. M., \& Liao, J. (2015). The positive impact of high performance work systems (HPWS) on employee commitment and self-sufficiency in strategic human resource management (SHRM) in Kurdistan. European Journal of Business and Management, 7(3), 80-109.

[38] Super, D. E. (1969). Vocational development theory: Persons, positions, and processes. The counseling psychologist, 1(1), 2-9.

[39] Tahir, N., Yousafzai, I. K., Jan, S., \& Hashim, M. (2014). The Impact of Training and Development on Employees Performance and Productivity A case study of United Bank Limited Peshawar City, KPK, Pakistan. International Journal of Academic Research in Business and Social Sciences, 4(4), 86.

[40] Thunnissen, M., Boselie, P., \& Fruytier, B. (2013). Talent management and the relevance of context: Towards a pluralistic approach. Human Resource Management Review, 23(4), 326-336.

[41] Wall, T. D., Wood, S. J., \& Leach, D. J. (2004). Empowerment and performance. International review of industrial and organizational psychology, 19, 1-46.

[42] Yohe, S. W., \& Hatfield, L. (2003, July). Moderating factors in participative management. In Allied Academies International Conference. Academy of Organizational Culture, Communications and Conflict. Proceedings (Vol. 8, No. 2, p. 33). Jordan Whitney Enterprises, Inc

[43] Zakuan, Z. Z. M., \& Saian, R. الموضوع: Trusted Environment for E-Commerce in Malaysia: An Overview.

*Corresponding author.

E-mail address: moza.sheikh21@gmail.com 